\title{
Customer Intention to Commit Motor Insurance Fraud: A Literature Review
}

\author{
Nurul Hidayah Mohd Yusof ${ }^{\mathrm{a}}$, Ahmad Zainal Abidin Abd Razak ${ }^{\mathrm{b}}$ \\ ${ }^{\text {a }}$ Faculty of Management and Economics, Universiti Pendidikan Sultan Idris, Malaysia, \\ nurulhidayah_me@yahoo.com.my \\ ${ }^{\mathrm{b}}$ Faculty of Management and Economics, Universiti Pendidikan Sultan Idris, Malaysia, \\ ahmad.zainal@fpe.upsi.edu.my
}

\begin{abstract}
Fraud in insurance is becoming an interesting issue nowadays among researchers and parties involved in the industries. Increase in numbers of insurance claim leads to unstable and unpredictable operating profit suffered by insurance companies. These claims are believed to include both bogus and authentic claims. Thus, the aim of this study is to examine customers' intentions in committing motor insurance fraud. The objective is to determine the relationship between individual attitude and subjective norms on intention to commit motor insurance fraud. The sample for this study will be teachers from selected schools in Petaling District, Selangor. Data from the respondents will be collected using questionnaires. Statistical Package for Social Science (SPSS) will be used to analyze the data collected. Specifically, correlation and regression will be used to test the hypothesis. Finding from this study is believed useful for insurance regulator and industry to handle insurance fraud attempts.
\end{abstract}

\section{Keywords:}

Fraud, Insurance, Motor, Motor Insurance, Theory of Reason Action

\section{INTRODUCTION}

Insurance industry plays an important role in protecting individuals, businesses and organizations from any financial risks (European Systemic Risk Board, 2015). Many insurance companies, support development of various industries like engineering, marine and automotive by offering variety risk management programs (Edward et al., 2017). Furthermore, the development of the insurance market in a country has been contributed by many factors such as an increase in income, the stability of macroeconomics and financial deepening (Beck \& Webb, 2003). Yet, insurance fraud has become a huge threat in the insurance industry profitability (Yusuf $\&$ Babalola, 2009). Thus, the aim of this study is to determine the influence of individual attitude and subjective norms on intention to commit motor insurance fraud. It is useful for the insurance regulator and industry to understand it in combatting the rampant issue of fraud in the motor insurance industry.

\section{PROBLEM STATEMENT}

From prior research done, at international level, the insurance company is facing billions of dollars of losses every year due to insurance fraud (Yusuf \& Babalola, 2009). As for domestic insurance company, Malaysian insurance companies, operating profit for the general insurance industry starting from 2013 until 2017 was reported to be unstable (Bank Negara Malaysia, 2017). The record showed, in the year 2003 alone, there were 437 fraud 
cases reported involving a loss of RM10.9 million (Bernama, July 20, 2005). While in 2009, it has increased to RM1.74 billion losses suffered by the insurance industry due to fraud. This amount represents almost $20 \%$ of the total claim amount paid in that year. This amount increases rapidly over the next few years. As proof, it was reported that in the year 2013 alone, RM760 million losses were incurred by motor insurance and the takaful industry in Malaysia (Bank Negara Malaysia Online, May 28, 2015). From the observation made by the industry, it was believed that 3\% to 5\% of total insurance claims in Malaysia have elements of fraud (Berita Harian Online, July 6, 2010). For survival, the insurance companies are transferring all the loss burden to the customer by increasing the premium price (Mudzamir Mohamed, 2013). This provides a clear overview of the importance of addressing fraud issues instantly. Failure to do so, it may affect insurance companies' profits, the growth of insurance firms, national economic growth (Tseng, Kang \& Chung, 2014).

\section{LITERATURE REVIEW}

\section{Theory of Reasoned Action (TRA)}

According to TRA, attitude and subjective norms lead to human intention to perform a certain behaviour. Intention becomes a driver to motivate a person to perform an action (Pavlou \& Fygenson, 2006). The higher the intention level, the possibility of an individual to perform the act will become stronger (Ram Al Jaffri \& Roszaini, 2014). Thus TRA is deemed suitable to be used as the underlying theory for this research. TRA has been used by many researchers in studying human intention (Ram Al Jaffri \& Roszaini, 2014; Sulaiman, Mustafa \& Rusni, 2016; and Zhikun \& Fungfai, 2009). For example, Ram Al Jaffri and Roszaini (2014), in their research regarding 'zakat' compliance behavioural, have found that attitude and subjective norms influence Malaysian businessman's intention to pay business 'zakat'. Similarly, studies by Sulaiman, Mustafa \& Rusni (2016) found that attitude positively influences public behavioural intention to adopt Islamic banking in Uganda.

\section{Individual Attitude}

Attitude is the tendency of a person to react to something either in a positive or negative way (Lee, 2012). It is the expression of an individual's behavioural belief (Hassandoust \& Perumal, 2010). The creation of feelings depends on an individual's belief (trust) and their evaluations on the expected result of that behaviour (Chang, 1998).

Motor insurance is normally handled by the third party like agent and workshop. Thus, the attitude of the customer towards the third party becomes crucial. People are prone to create a positive intention to a person who he trusts (Aydin \& Ozer, 2005). Trust is important since it creates a comfortable environment for the customer to share their personal information (Bianchi \& Andrews, 2012). In a motor insurance claim environment, the third parties are trusted to act on behalf of the customer. They deal directly with the insurance company and prepare all the documents needed with the co-operation from the customer (Edward et. al, 2017). The information sharing between customers and third parties is only possible if the trust exists. This is especially when the penalties imposed to the fraudster is serious (Financial Service Act, 2013).

Besides that, confidence can also influence human attitude (Bohner \& Wanke, 2002). Customer's engagement with third parties is influenced by the reduction of anxiety and 
emotional comfort gained from the services received (Kinard \& Capella, 2006); (Patterson \& Smith, 2001). Confidence is needed to evaluate the consequences of future action (McDonald \& Oates, 2006). In a risky environment like insurance fraud, confidence of success is vital before performing the action. If the level of confidence is high, there is a possibility for the action to be performed (Ajzen, 2012).

\section{Subjective Norms}

Other than customer's attitude, the subjective norm is also affecting individual's intention (Bock et. al, 2005). Subjective norm is created by the combination of normative belief and motivation to comply (Ha \& Janda, 2012). Subjective norms is a social pressure perceived by the participant to engage in certain behaviors (Ajzen, 2012). Normally, people are prone to behave in accordance with his social group which comprises of family members, peers and all people in the surroundings (Childers \& Rao, 1992). The effects of subjective norms can be clearly be seen if it is tested in a collectivism country like Asian (Aramand, 2012); (Srite \& Karahanna, 2006). The Asian country is believed to have a high tendency to make decision-based on intuitive examination of its surrounding and system (Burger \& Herstein, 2014). Thus, Malaysians are believed to have a high propensity to trust others in their decision making (Gong, 2009).

Normative beliefs are defined as things which are accepted by social behavior that makes a person do something (Huesmann \& Guerra, 1997). The degree of social acceptance on the maladaptive attitudes will influence an individual's intention to perform a behavior (Jurkovic, 2014). From previous research done on insurance fraud by Tennyson (1997 \& 2008) and Brinkmann (2005), they found that insurance fraud is not considered as an ethical problem by the public and thus becomes ethically acceptable which could lead to more fraudulent behavior (Tseng \& Shih, 2012). On such community perceptions and acceptance of fraud, it can probably initiate a person's intention to commit fraud because it seems normal and allowed by all. This perception actually reduces an individual's sense of guilt when committing offenses.

Meanwhile, motivation can bring effects to human intention since it indicates a person's passion, willingness, and effort on something to perform the behavior (Ajzen, 1991; Organ et al., 2013). According to Wright (2007), fraud is something that relates to economic motivation. Thus, greediness of a person possibly contributes to this issue. This happens especially when a person is in desperate need for money. This situation makes a person creates a belief of entitlement to something (compensation) which is actually not theirs (Freedman et al., 2009). In such desperate situations, people are usually willing to take risks and try to rationalize their unethical behavior. Furthermore, social communication and messages become the main sources of information tools (Aramand, 2012). Since people in a collectivist culture tend to hear and believe in others' opinions, thus, positive or negative perceptions from the community can affect a person's judgment, behavior and also become external motivation to others. 


\section{FRAMEWORK}



Figure 1: Conceptual framework

The above proposed conceptual framework reveals the relationship between individual attitude and subjective norms as independent (IV) variables and intention to fraud as dependent variables (DV) that would be tested. The framework was adapted from the basic Theory of Reasoned Action (TRA) by Ajzen \& Fishben (1980) and Fishben \& Ajzen (1975).

\section{METHODOLOGY}

In order to fulfill the research objectives and answer the research questions, a cluster sampling technique will be used for this study. The study will be conducted in five selected schools in Selangor, Malaysia. The state of Selangor will be the chosen state to conduct the study since it recorded the highest number of accident cases. Teachers are selected as the respondents since teachers are highly educated who are usually more ethical (Brokesova \& Pastorakova, 2013) and has a high level of integrity compared to the less educated person (Nor Salmi \& Lim Hooi,2011). A self-administered questionnaire will be used to collect the data. Descriptive analysis, factor analysis, reliability measures, correlation and regression analysis will be conducted to analyze the data. The questionnaire will consist of eight parts and the instrument used in developing the questionnaire are from various sources. Demographic questions such as gender, age, education level, individual and household income, ownership of vehicle and type of vehicle owned will also be collected. However, some personal information of the respondents such as name, email address and others will not be asked in the questionnaire to ensure the confidentiality of the respondent. Table 1, indicates the summary of measurements that will be used in this study. 
Table 1:Summary of measurements used for the study

\begin{tabular}{|c|c|c|c|c|}
\hline $\begin{array}{l}\text { Author/s \& } \\
\text { Year }\end{array}$ & $\begin{array}{l}\text { No of } \\
\text { Items }\end{array}$ & Measuring & $\begin{array}{l}\text { Cronbach } \\
\text { alpha }\end{array}$ & Scale \\
\hline Bianchi \& & 4 & to the & 0.82 & Likert scale ranging \\
\hline Andrews (2012) & & Third Party & 0.77 & $\begin{array}{l}\text { from (1) totally disagree } \\
\text { to (4) totally agree. }\end{array}$ \\
\hline $\begin{array}{l}\text { Chuchinpr } \\
\text { akarn (2005) }\end{array}$ & 3 & $\begin{array}{l}\text { Confident of } \\
\text { Claim's } \\
\text { Successfulness }\end{array}$ & - & $\begin{array}{l}\text { Likert scale ranging } \\
\text { from (1) totally disagree } \\
\text { to (4) totally agree. }\end{array}$ \\
\hline $\begin{array}{l}\text { Vallerand et al. } \\
\text { (1992) }\end{array}$ & 4 & $\begin{array}{l}\text { Normative } \\
\text { Beliefs }\end{array}$ & 0.88 & $\begin{array}{l}\text { Likert scale ranging } \\
\text { from (1) very false to } \\
\text { (4) Very true }\end{array}$ \\
\hline $\begin{array}{l}\text { Vallerand et al. } \\
\text { (1992) }\end{array}$ & 4 & Motivation & 0.78 & $\begin{array}{l}\text { Likert scale ranging } \\
\text { from (1) totally disagree } \\
\text { to (4) totally agree. }\end{array}$ \\
\hline $\begin{array}{l}\text { Vallerand et al. } \\
\text { (1992) }\end{array}$ & 3 & $\begin{array}{l}\text { Individual } \\
\text { Attitude } \\
\text { towards Fraud }\end{array}$ & 0.88 & $\begin{array}{l}4 \text { point likert scale } \\
\text { ranging from: } \\
\text { (1) very bad (4) very } \\
\text { good } \\
\text { (1) stupid (4) intelligent } \\
\text { (1) harmful (4)beneficial }\end{array}$ \\
\hline $\begin{array}{l}\text { Francis et al. } \\
(2004)\end{array}$ & 3 & $\begin{array}{l}\text { Subjective } \\
\text { Norm }\end{array}$ & - & $\begin{array}{l}\text { Likert scale ranging } \\
\text { from (1) very false to } \\
\text { (4) very true }\end{array}$ \\
\hline $\begin{array}{l}\text { Calisir, } \\
\text { Gumussoy \& } \\
\text { Bayram (2009) }\end{array}$ & 6 & $\begin{array}{l}\text { Intention } \\
\text { Fraud }\end{array}$ & 0.89 & $\begin{array}{lll}\text { Likert } & \text { scale } & \text { ranging } \\
\text { from } & (1) & \text { strongly } \\
\text { disagree } & (4) & \text { strongly } \\
\text { agree } & & \end{array}$ \\
\hline $\begin{array}{l}\text { Benjamin } \& \\
\text { Samson (n.d) }\end{array}$ & 3 & & - & \\
\hline
\end{tabular}

\section{CONCLUSION}

This research article will provide some preliminary understanding of motor insurance fraud issues in Malaysia, using TRA. It is believed that intention to commit fraud depends on two factors which are individual attitude and subjective norms. Finding from this study is believed to be useful for insurance regulator and industrial companies in combatting the rampant issue of fraud in the motor insurance industry. By understanding the cause, an effective strategy could be initiated in overcoming the problem. Thus, the growth of the insurance industry will not be affected and insurance customers will not be victimized by the premium increase. 


\section{References}

Aramand, M. (2012). Women entrepreneurship in Mongolia : the role of culture on entrepreneurial motivation. International Journal, 32, 68-82. http://doi.org/10.1108/02610151311305623.

Ajzen, I. (2012). The theory of planned behavior. In P. A. M. Lange, A. W. Kruglanski \& E. T. Higgins (Eds.), Handbook of theories of social psychology, 1, 438-459.

Ajzen, I. (1991).The theory of planned behavior. Organizational Behavior and Human Decision Processes, Vol. 50 No. 2, pp. 179-211.

Ajzen, I. \& Fishbein, M. (1980), Understanding Attitudes and Predicting Social Behaviour, PrenticeHall, Englewood Cliffs, NJ

Aydin, S. \& Ozer, G. (2005).Customer loyalty and the effect of switching costs as a moderator variable: a case in the Turkish. Marketing Intelligence and Planning, Vol. 23 No. 1, pp. 89103.

Bank Negara Malaysia (2015). Deputy Governor's Keynote Address at the Insurance Information \& Ratemaking Forum of Asia 2015 (IIRFA) on May 28, 2015. Retrieved on November 23, 2016 from http://www.bnm.gov.my/index.php?ch=en_speech\&pg=en_speech\&ac $=560 \& l a n g=e$

Bank Negara Malaysia (2017). Management Expenses for General Insurance. Retrieved on August 15, 2017 from http://www.bnm.gov.my/index. php?ch=en_publication\&pg= en_msb\&ac= $248 \&$ bm\&uc $=2$

Beck, T. \& Webb, I. (2003).Economic, Demographic, and Institutional Determinants of Life Insurance Consumption across Countries. The World Bank Economic Review, Vol. 17, No. 1, pp. 51-88.

Benjamin, O. A., \& Samson, B. S. (2011). Effect of perceived inequality and perceived job insecurity on fraudulent intent of bank employees in Nigeria. Europe's Journal of Psychology, 7(1), 99111. doi:10.5964/ejop.v7i1.107.

Bernama (2005, July, 20). UiTM EZAccess. Retrieved 13 March 2015, from http://blis2.bernama.com.ezaccess.library.uitm.edu.my/mainHome Bypass.do

Berita Harian (2010, July 06). Nilai Penipuan Tuntutan Insurans Cecah RM1.74 Bilion. Retrieved 12 June 2016 from http://www.bharian. com.my/bharian/ articles/NilaipenipuantuntutaninsuranscecahRM1.74 bilion/Article/

Bianchi, C., \& Andrews, L. (2012). Risk, trust, and consumer online purchasing behaviour: a Chilean perspective. International Marketing Review,29(3), 253-275. doi:10.1108/ 02651 331 211229750 .

Bock, G., Zmud, R.W., Kim, Y. \& Lee, J. (2005). Behavioral intention formation in knowledge sharing: examining the roles of extrinsic motivators, social-psychological forces, and organizational climate. MIS Quarterly, Vol. 29 No. 1, pp. 87-111.

Bohner, G. \& Wanke, M. (2002), Attitudes and Attitude Change, Psychology Press, Brighton.

Burger, R. \& Herstein, R. (2014).The evolution of business ethics in India. International Journal of Social Economics, Vol. 41 No. 11, pp. 1073-1086.

Brinkmann, J. (2005).Understanding insurance customer dishonesty: outline of a situational approach. Journal of Business Ethics, Vol. 61, pp. 183-97.

Brokesova, Z., \& Pastorakova, E. (2013). The Relalationships Between Selected Demographic Fators and Acceptability of Consumer Insurance Fraud. European Scientific Journal, 1, 297-304. 
Calisir, F., Gumussoy, C. A., \& Bayram, A. (2009). Predicting the behavioral intention to use enterprise resource planning systems: An exploratory extension of the technology acceptance model. Management Research News, 32(7), 597-613. http://doi.org/10.1108/0140917091096521

Chang, M.K. (1998). Predicting unethical behaviour: a comparison of the theory of reasoned action and the theory of planned behaviour. Journal of Business Ethics, Vol. 17, pp. 1825-34.

Childers, T. L. \& Rao, A. R. (1992). Childers and Hale 1. Journal of Consumer Research, 19, 1-14. Retrieved from http://int.search.tb.ask.com/search/ Gmain.jhtml

Chuchinprakarn, S. (2005). Application of the Theory of Reasoned Action to Online Shopping. 1-7. Retrieved from http://www.bu.ac.th/knowledgecenter/epaper/jan_june2005/supanat.pdf

Crocker, K. J., \& Morgan, J. (1998). Is Honesty The Best Policy? Curtailing Insurance Fraud Through Optimal Incentives Contracts. Journal Of Political Economy, Vol. 106, Pp. 355-375.

Edward, O. T., Azitadoly Mohd Arifin, Ainon Basar, Nurul Aida Harun, Norfaezah Mohd Shahren \& Faziatul Amilia Mohamad Basir (2017). Risk and Insurance. $3^{\text {rd }}$ edition. Shah Alam: McGrawHill Education.

European Systemic Risk Board. (2015). Report on systemic risks in the EU insruance sector: The role of the insurance sector in the economy (Vol. Annex 1). Retrieved from https://www.esrb.europa.eu/ pub/pdf /other/2015-1216_esrb_report_annex_1.pdf?e1981f8cd92 dc43f89dd154067e2ba49

Financial Service Act (2013). Law of Malaysia. Retrieved from http://www.bnm.gov.my/ index.php?ch=en_legislation\&pg=en_legislation_act\&ac=221\&lang=en . on14 January 2016.

Fishbein, M. Ajzen, I. (1975). Belief, Attitude, Intention and Behavior: An Introduction to Theory and Research, Addison-Wesley, Reading, MA.

Francis, J., Eccles, M., Johnston, M., Walker, A., Grimshaw, J., Foy, R., Bonnetti, D.(2004). Constructing questionnaires based on the Theory of Planned Behaviour: A manual for health services researchers. Newcastle upon Tyne, UK: Centre forHealth Services Research, University of Newcastle

Freedman, D., Kranacher, M., Maguire-krupp, M., Owens, C., Ratley, J., Riley, R., \& Wells, J. (2009). Bringing Freud to Fraud: Understanding the State-of-mind of the C-Level Suite / White Collar Offender Through "A-B-C” Analysis. West Virginia University.

Gong, W. (2009). National culture and global diffusion of business to consumer e-commerce. National Culture and Global Diffusion, Vol. 16 No. 1, pp. 83-101.

Ha, H.Y., \& Janda, S. (2012). Predicting consumer intentions to purchase energy-efficient products. Journal of Consumer Marketing, 29(7), 461-469. http://doi.org/10.1108/07363761211274974

Hassandoust, F. \& Perumal, V. (2010). Socio-behavioral factors in virtual knowledge sharing: theory of reasoned action and theory of planned behavior perspective. Virtual Conference on Business and Management, Vol. 2 No. 1, pp. 91-107.

Huesmann, L., \& Guerra, N. G. (1997). Children's normative beliefs about aggression and aggressive behavior. Journal of Personality \& Social Psychology, 72(2), 408-419.

Jurkovic, A. (2014). Normative Beliefs as a Mediator between Body Dissatisfaction and Disordered Eating. Honors Projects. Paper 162.http: //digitalcommons. iwu.edu/psych_honproj/162. 
Kinard, B.R. \& Capella, M.L. (2006). Relationship marketing: the influence of consumer involvement on perceived service benefits. Journal of Services Marketing,Vol. 20,pp.359-368.

KPMG Malaysia. (2013). KPMG Malaysia Fraud, Bribery and Corruption Survey 2013. Retrieved from www.frank-cs.org/cms/pdf/ KPMG/KPMG_Malaysia_Survey_13.1.14.pdf on 12 April 2017.

Lee, B. C. Y. (2012). The determinants of consumer attitude toward service innovation - the evidence of ETC system in Taiwan. Journal of Services Marketing, 26(1), 9-19. http://doi.org/10.1108/ 08876041211199689

McDonald, S. \& Oates, C.J. (2006). Sustainability: consumer perceptions and marketing strategies. Business Strategy and the Environment, Vol. 15 No. 3, pp. 157-70.

Miyazaki, A.D. (2009). Perceived ethicality of insurance claim fraud: do higher deductibles lead to lower ethical standards?", Journal of Business Ethics, Vol. 87 No. 4, pp. 589-98.

Mudzamir Mohamed. (2013). Countering Fraud in the Insurance Industry-:A Case Study of Malaysia. Institute of Criminal and Justice Studies,University of Portmouth.

Nor Salmi, A.Z. \& Lim, H.L.(2011). Mengkaji Kesahan Inventori Nilai Integriti Dalam Kalangan Guru-guru Sekolah Rendah. Retrieved 25 June 2015 from http://education.usm.my/ images/ docs/ MEDC/VOL7/1.pdf

Organ, S., Proverbs, D., Squires, G., Organ, S., Proverbs, D., \& Squires, G. (2013). Motivations for energy efficiency refurbishment in owner-occupied housing. Structural Survey, 31(2), 101120. doi:10.1108/02630801311317527.

Patterson, P.G. \& Smith, T. (2001). Relationship benefits in service industries: a replication in a Southeast Asian context. Journal of Services Marketing, Vol. 15, pp. 425-443.

Pavlou, P.A. \& Fygenson, M. (2006). Understanding and predicting electronic commerce adoption: an extension of the theory of planned behavior. MIS Quarterly, Vol. 30 No. 1, pp. 115-143

Ram Al Jaffri Saad \& Roszaini Haniffa, (2014). Determinants of zakah (Islamic tax) compliance behavior. Journal of Islamic Accounting and Business Research, Vol. 5 Issue: 2, pp.182-193, https://doi.org/10.1108/ JIABR-10-2012-0068

Sulaiman Lujja, Mustafa Omar Mohammad, Rusni Hassan, (2016). Modelling public behavioral intention to adopt Islamic banking in Uganda: The theory of reasoned action. International Journal of Islamic and Middle Eastern Finance and Management, Vol. 9 Issue: 4, pp.583-600, https:// doi.org/10.1108/IMEFM-08-2015-0092

Srite, M. \& Karahanna, E. (2006). The role of espoused national cultural values in technology acceptance. MIS Quart, Vol. 30 No. 3, pp. 679-704.

Tennyson, S. (1997). Economic institutions and individual ethics: a study of consumer attitudes toward insurance fraud. Journal of Economic Behaviour \& Organization, Vol. 32, pp. 247265.

Tennyson, S. (2008). Moral, social, and economic dimensions of insurance claims fraud. Social Research, Vol. 74 No. 4, pp. 1181-2.

Tseng, L.M., Kang, Y.M., \& Chung, C.E. (2014). Understanding the roles of loss-premium comparisons and insurance coverage in customer acceptance of insurance claim frauds. Journal of Financial Crime , 321-335. 
Tseng, L.-M., \& Shih, M.-F. (2012). Consumer attitudes toward false representation. Journal of Financial Crime, 19(2), 163-174. http://doi.org/10.1108/13590791211220430

Vallerand, R.J., Pelletier, L.G. , Deshaies, P., Cuerrier, J. P. \& Mongue, C. (1992). Ajzen and Fishben "s theory of reasoned action as applied to moral behavior : A confirmatory analysis. Journal of Personality and Social Psychology, Vol. 62, No. 1, pp. 98-109.

Wright, R. (2007). Developing Effective Tools To Manage The Risk Of Damage Caused By Economically Motivated Crime Fraud (Vol. 14, Pp. 17-27): Journal Of Financial Crime.

Yusuf, O.T. \& Babalola, A.R. (2009). Control of insurance fraud in Nigeria: an exploratory study (case study). Journal of Financial Crime, Vol. 16 No. 4, pp. 418-435.

Zhikun, D., \& Fungfai, N. (2009). Knowledge Sharing Among Architects in a Project Design Team: An Empirical Test of Theory of Reasoned Action in China. Chinese Management Studies, 3(2), 130-142. http://doi.org/10.1108/17506140910963639 